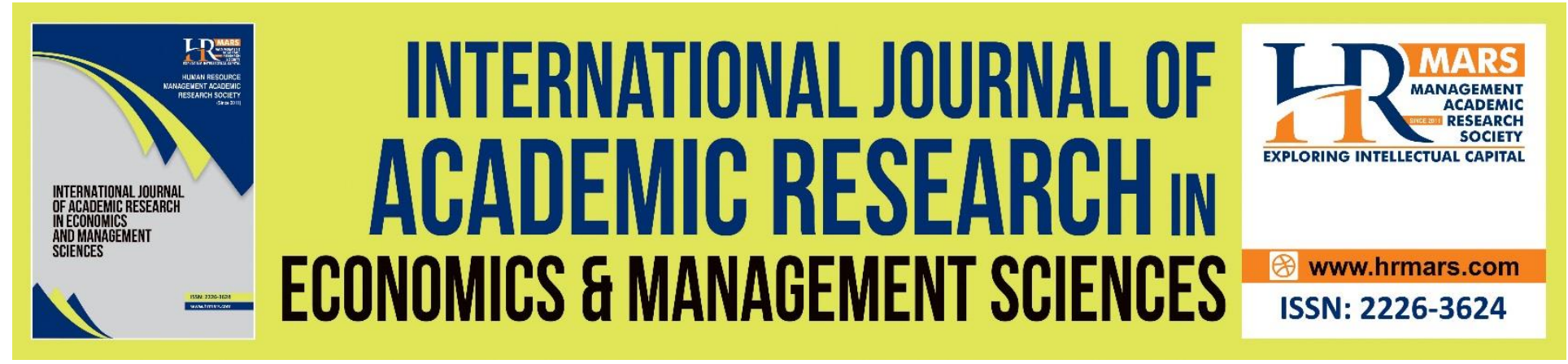

\title{
Crowdfunding System Models in the African Context: The Susu and Yibima Concepts in Ghana
}

Francis Kwaku Kuma, Mohd Effandi Yusoff, Jerome Jayamana

To Link this Article: http://dx.doi.org/10.6007/IJAREMS/v10-i3/11039 DOI:10.6007/IJAREMS/v10-i3/11039

Received: 23 July 2021, Revised: 29 August 2021, Accepted: 12 September 2021

Published Online: 25 September 2021

In-Text Citation: (Kuma et al., 2021)

To Cite this Article: Kuma, F. K., Yusoff, M. E., \& Jayamana, J. (2021). Crowdfunding System Models in the African Context: The Susu and Yibima Concepts in Ghana. International Journal of Academic Research in Economics and Management and Sciences, 10(3), 359-374.

Copyright: @ 2021 The Author(s)

Published by Human Resource Management Academic Research Society (www.hrmars.com)

This article is published under the Creative Commons Attribution (CC BY 4.0) license. Anyone may reproduce, distribute, translate and create derivative works of this article (for both commercial and non-commercial purposes), subject to full attribution to the original publication and authors. The full terms of this license may be seen

at: http://creativecommons.org/licences/by/4.0/legalcode

Vol. 10, No. 3, 2021, Pg. 359 - 374

http://hrmars.com/index.php/pages/detail/IJAREMS

JOURNAL HOMEPAGE

Full Terms \& Conditions of access and use can be found at http://hrmars.com/index.php/pages/detail/publication-ethics 


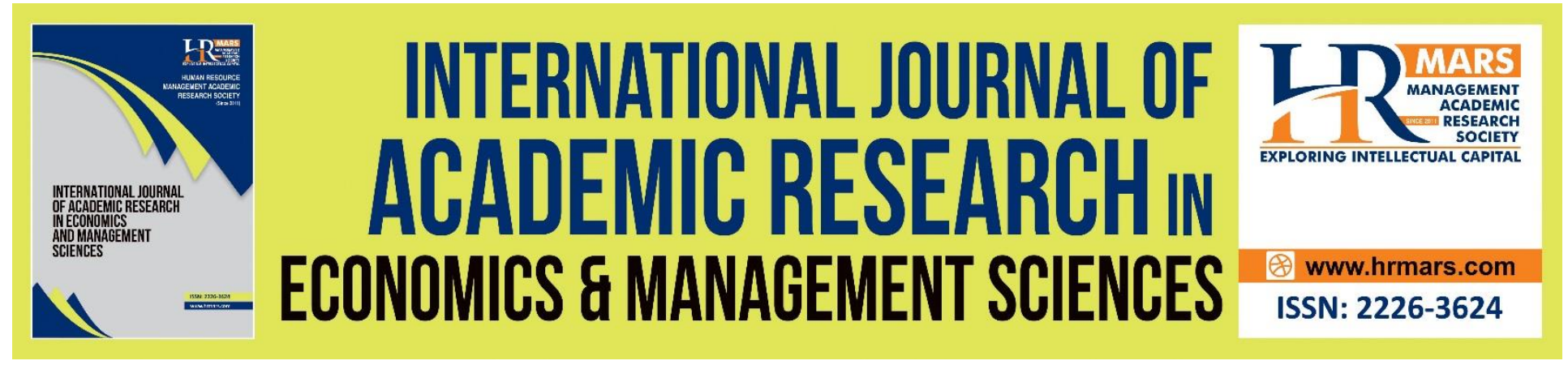

\title{
Crowdfunding System Models in the African Context: The Susu and Yibima concepts in Ghana
}

\author{
Francis Kwaku Kuma \\ ${ }^{1}$ Universiti Teknologi Malaysia Skudai, Johor Bahru 81310, Department of Accountancy, \\ Koforidua Technical University, Ghana \\ Email: kwakuhull@gmail.com \\ Dr Mohd Effandi Yusoff \\ ²Universiti Teknologi Malaysia Skudai, Johor Bahru \\ Email: effandi@utm.my \\ Jerome Jayamana \\ ${ }^{3}$ Raffles University Iskanda Johor Bahru, Malaysia \\ Email: jeromejayamana@gmail.com
}

\begin{abstract}
The study examines the operations of Susu, which is a Ghanaian indigenous crowdfunding concept of fund mobilization in support of micro enterprises. The study further explores a typology of the Susu concept known as Yibima, which is an emerging concept, which has not been explored by existing literature. The key concepts of these indigenous crowdfunding models are critically considered and the study is conducted using qualitative research method. The study presents an inductive approach from data samples using Grounded Theory to develop a theoretical framework for the study. There was a constant comparison of analyzed data, grounded theory coding, observation and personal experience to come out with a theoretical view that Susu bears similarities with crowdfunding and that Yibima is a typology of Susu that has not been explored by other scholars. This assertion is reinforced by the application of inductive reasoning based on interview data. The findings, therefore, reveal that during Yibima campaigns, project initiators make a general appeal to the public (crowd) and these campaigns are launched on social media platforms and funds raised from such campaigns could be used as startup capital for business ventures or for supporting community projects. Following on the reviewed of existing literature and based on Grounded Theory from analyzed data, the study put forward a theory that Susu satisfies all the conditions to be classified as a crowdfunding concept. In addition, the findings also shows that Yibima satisfies the requirements to be a typology of the Susu as a concept.
\end{abstract}

Keywords: Crowdfunding, Susu, Yibima, Grounded Theory, African Context 


\section{Introduction}

The study attempts to establish a link between Susu, which is an overarching form of indigenous crowd financing in Ghana and the modern-day concept of Crowdfunding (CF). In trying to achieve our aim, we reviewed the defining literature on Susu and crowdfunding concepts in detail and evaluated applications of these in practical terms. In particular, we critically considered the key concepts of these theories and how they could be applied in practical terms. Existing research suggests that crowdfunding, just like Susu, serves as an alternative source of funding for most micro enterprises because of the inability of these micro enterprises to raise funds from the banks and other traditional sources. We also introduced Yibima, a new definition of the concept, which has not been covered in literature and included it as a typology of the known Susu models. The question therefore is: does any form of crowdfunding exist in the traditional African context? We therefore categorized the research problem set for this study as follows: First, we aimed to study and explain Susu as a crowdfunding concept. Second, we explored a justification for including Yibima as a typology of the Susu concept and provided a definition for it.

\section{Literature Review}

Much of the literature on crowdfunding credited the origin of crowdfunding to Europe and America but unfortunately, no cognizance was taken of the fact that the crowdfunding concept existed in various forms in traditional settings in Africa. A growing body of knowledge has suggested that some forms of crowdfunding existed in the $16^{\text {th }}$ century in some African communities in the form of spirit of communal reciprocity (Dieter, 2001; Aryeetey, 2005). This took the form of pooling of resources together in support of micro enterprises of the members of the community (Wolf, 2017). Again, it was used to support communal projects, which were organized by opinion leaders of the community. For instance, ample evidence suggest that the Kenyan culture practiced the Harambee system for ages (Vershinina et al., 2018). Under the Harambee ${ }^{1}$ system of communal practice, members of the community provided goods through voluntary cooperation. Similarly, in Ghana, the Susu fund mobilization concept operated about 300 years ago among most Ghanaian communities (Aryeetey, 2005).

\section{The Susu Concept in Ghana}

As discussed in prior literature, the Susu saving concept is a traditional or informal finance in Ghana, which is similar to the Arisan system, operated in Indonesia and Paluwagan in the Philippines (Dieter, 2001). Currently, there is a lack of clarity on the etymology of the word because while some scholars are of the view that Susu is an Akan word which means 'bit-by-bit' (Osei-Assibey, 2015), other scholars believe it is a Ga word which means 'measure' or 'plan' (Alabi et al., 2007).

The above confusion notwithstanding, it is evidently clear that Susu is a form of saving mobilization among rural and urban poor in Ghana. This form of indigenous savings gives the people access to credit as a startup capital for their businesses (Anku-Tsede, 2013). The Susu therefore, in a way, assists Ghanaians in lower income brackets to save small amounts on daily or weekly basis (Aryeetey, 2005). In fact, it is regarded as one of the oldest forms of moneycollecting system in Ghana (Gyasi et al., 2019; Ayensu et al., 2016). Nevertheless, for the purpose

1 The term "Harambee" means, "let us pull together"(Berndt et al., 2016) 
of this study, we focused on the crowdfunding aspect of Susu, which has not been exploited effectively by existing literature.

\section{Operations of the Susu concepts}

Centering on certain specifics, under the Susu system, usually, a pool is created and members of the group make financial contributions into this pool in a form of savings (Seibel, 2001; Steel and Andah, 2003; Quaye et al., 2014). The drawings from the pool is advanced to members on rotational basis depending on the numerical position on the list of members until every member of the group receives their fair share of the contributions (Aryeetey, 2005). The process starts all over again after every member of the group is served (Anku-Tsede, 2013). In a number of significant ways, the Susu system serve as an alternate source of finance to micro enterprises such as dressmaking, bead making, carpentry and other artisans (Alabi et al., 2007). As the name indicates, Susu as a form of indigenous crowd funding plays a vital role in assisting the group members plan their finances (Mensah and Rengarajan, 2019). Empirical evidence on the Susu concept from existing literature is presented in Table 1.

Table 1: Empirical Results for the Susu concept

\begin{tabular}{|l|l|}
\hline Author & Empirical Evidence \\
\hline Aryeetey (1994) & A financial phenomenon found mostly in developing countries \\
\hline Aryeetey and Udry (1995) & $\begin{array}{l}\text { As a social phenomenon, Susu forms part of the financial } \\
\text { system unregulated by formal rules. }\end{array}$ \\
\hline Dieter (2000) & $\begin{array}{l}\text { Groups providing social insurance by allocating scarce } \\
\text { resources, out of turn, to members in emergencies. }\end{array}$ \\
\hline Steel and Andah (2003) & $\begin{array}{l}\text { The susu system primarily offers savings products to help } \\
\text { clients accumulate their own savings. }\end{array}$ \\
\hline Alabi (2007) & $\begin{array}{l}\text { Susu is believed to have contributed largely to micro } \\
\text { enterprises and small scale businesses. }\end{array}$ \\
\hline Anku-Tsede (2013) & $\begin{array}{l}\text { Susu has been part of Ghana's micro financial system for at } \\
\text { least three centuries. }\end{array}$ \\
\hline Osei-Assibey (2015) & $\begin{array}{l}\text { Susu represents the pooling of money resources from } \\
\text { numerous sources to get a larger sum. }\end{array}$ \\
\hline
\end{tabular}

Source: Author's construction

\section{Taxonomy of Susu}

Susu has various models and the summary of the models are presented in Figure 1. Existing research have identified about three types of Susu models, which differ in terms of the contributions they receive and the rewards they offer to backers (Alabi et al., 2011). They also differ in terms of the purposes of the fundraisings (Aryeetey, 2005; Anku-Tsede, 2013; AmoahMensah, 2021). 
Susu Club Model: This model involves a type of a scheme where members of a group or club create a pool and members make financial contributions into the pool for a period of time (Aryeetey, 2005; Alabi et al., 2011; Anku-Tsede, 2013; Amoah-Mensah, 2021). The period ranges from weeks to months. In addition, the contributions depend entirely on the financial strength of the contributor (Anku-Tsede, 2013). Money from the pool is advanced to members of the club. Members can also borrow from the pool in support of their businesses.

Susu Associations Model: This is a form of fund mobilization concept where members of the association make financial contributions into a pool. The accumulated fund is then advanced to members as startup capital in support of their business ventures (Steel and Andah, 2003; AmoahMensah, 2021). This concept constitutes a form of communal support for members of the association. The size of the membership of the association depends largely on the location of the association (Aryeetey, 2005). The model has larger group membership in urban centers compared to rural communities (Osei-Assibey, 2015). Funds mobilized from members are advanced to members on rotational basis (Steel and Andah, 2003). In some instances, contributions are made to group members who need financial support in times of financial difficulties (Anku-Tsede, 2013).

Mobile Collectors Model: This form involves individual members of the public who act as platforms for fund mobilization among members of the community. Members therefore, make regular financial contributions to this financial intermediary who charges a fee for his services (Aryeetey, 2005; Alabi et al., 2011; Anku-Tsede, 2013; Amoah-Mensah, 2021). The contribution is in the form of daily savings and the amount of money a member can contribute depends on their financial circumstances.

Yibima Model: Yibima is a form of a crowd fundraising campaign usually adopted by members of the public, community groups and associations to support various project initiatives (Steel and Andah, 2003; Walker, 2017). Indeed, in some cases, Yibima campaigns are used to raise startup capital for members who are experiencing financial downturn in their business fortunes (Steel and Andah, 2003; Walker, 2017; Cicchiello et al., 2020; Amoah-Mensah, 2021). Yibima fundraising campaigns are also used to support community projects such as schools and hospitals (Steel and Andah, 2003; Anku-Tsede, 2013; Walker, 2017; Amoah-Mensah, 2021). This model is discussed in detail in section 4.1 . 


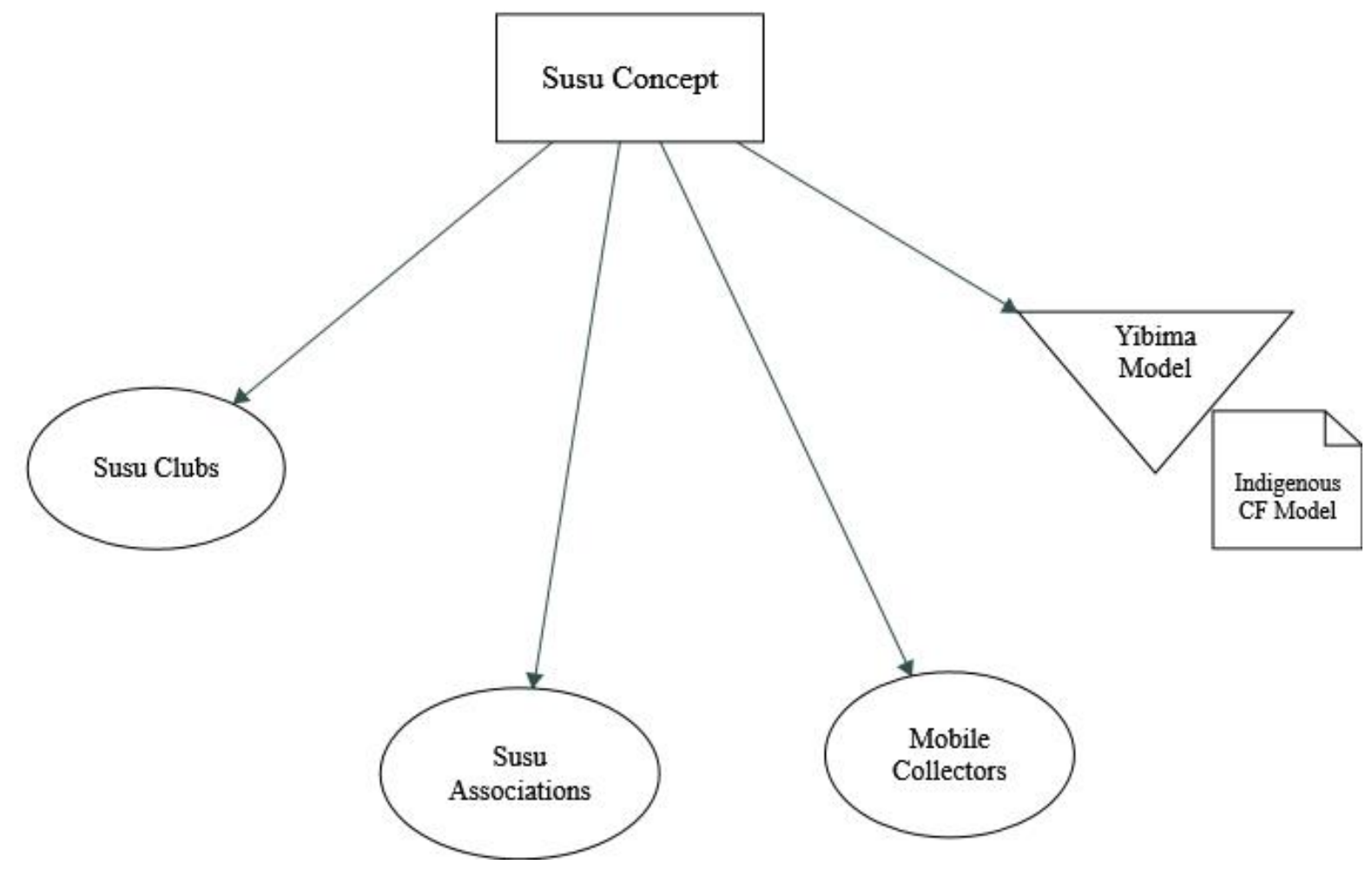

Figure 1: Taxonomy of the Susu concept

\section{Methodology}

We used an exploratory and inductive research approach to help set the narrative in the right context and to cater for the biases of the respondents (Alsharari and Al-Shboul, 2019). This approach is quite interactive and it gave the researchers an optional viewpoint and free interpretation of the elements of the study (Kaczynski et al., 2014; Hesse et al., 2019). In addition, it gave a better in-depth understanding and related specific observations to a more generalized point of view to relate the study to the changing environment. The study used qualitative approach for collecting the primary data to explore the relationship between Crowdfunding and Susu. The limitation of literature in this area of study, particularly, in Ghana, called for the adoption of this strategy. The study therefore aimed at developing evidence that there is a form of indigenous crowdfunding in existence in Ghana.

A qualitative-interview based research gave appropriate understanding and offered proper evaluation on how existing crowdfunding concepts could be accepted and formalized and expanded in the country. The study involved conducting semi-structured interviews to gain comprehensive understanding of the topic under study. This option offered a better structured approach and allowed for an option for in-depth analysis (Thorne, 2000). To explore this further, the designing of the research questions was based on the objectives of the study. Ultimately, regarding the interviewee type, the structure began with background information and questions 
relating to crowdfunding as alternate funding source for business ventures which were asked (Elliott, 2018). Prior to the preparation of the data for analysis, the interviews which were recorded on audio tapes were transcribed (Hesse et al., 2019). After setting out plans for the data analysis for the study, the recorded interviews were transcribed into a data set. The transcribed data for the purposes of analysis was coded using NVivo software program, which supports qualitative research (Elliott, 2018).

\section{Data Analysis}

We gathered our data through interviews with 21 participants in three academic institutions in Ghana. Most of the participants are academic staff with engineering and science background. The idea was to find out from them if CF could be used as alternate finance for the formation of academic spinoff companies. We were therefore, able to triangulate our findings to assess whether there is a link between CF and Susu because they bear some similarities. The study therefore, presents inductive approach for the samples on Susu using the Grounded Theory approach that is based on generalized views on four main grounded features (Guetterman et al., 2019). These are constant comparison from analyzed data, grounded theory coding, observation and personal experience. This view is therefore synthesized to come out with a theoretical view that Susu, which is a Ghanaian concept of resource mobilization, bears similarities to CF (Johnson, 2015).

This assertion is reinforced by the application of inductive reasoning based on interview data. Studies shows that Grounded Theory allows for the generating of theory from field data. It also allows for comparisons across cases to assess differences and similarities to allow generalizability. Barney Glaser and Anselm Strauss (1967) in developing this theory used certain grounded features such as constant comparison, saturation, grounded theory coding, memo, among others (Johnson, 2015; Guetterman et al., 2019). In conformity with the tenets of the Grounded Theory, the data was coded using NVivo software. During the coding, there was extraction of the codes with similar ideas or concept and during the coding, they were grouped into themes and subthemes (Maher et al., 2018). There was constant comparison between the codes to establish a connection between them. Based on this process, the theoretical model was developed using Grounded Theory (Johnson, 2015; Guetterman et al., 2019).

\section{Findings and Discussions}

The evidence emerging from analyzed data suggests that earlier literature on the Susu concept is focused on it being a concept of microfinancing system in support of business ventures (Aryeetey, 2005; Anku-Tsede, 2013). To some extent, the saving elements embedded in the concept were also highlighted (Osei-Assibey, 2015; Gyasi et al., 2019). However not much attention has been paid to the role of the crowd (community) in this indigenous funding raising concept. In addition, the donation aspect of the concept in support of community projects has not been given much attention. This could be attributed to the absence of the crowd in the early forms of Susu and the fact that Yibima as a crowdfunding system has not come to the attention of prior researches investigating the concept (Johnson, 2015). Even though the lending element, which is similar to P2P, was covered by literature, the linkage of that to Susu has not been explored further. 
In this paper, we introduce a novel approach to the Susu concept by putting forward the argument that the operations of the concept is similar to CF (Guetterman et al., 2019). More specifically, we argue that there is a typology of Susu which is a fundraising concept that takes the form of members of the community constituting a group of about 400 or more members pooling their resources together in support of a business venture of a member (Steel and Andah, 2003; Walker, 2017; Amoah-Mensah, 2021). This typology is discussed in detailed in section 4.1. Our study therefore aligns with a small number of others, which postulate that Susu campaigns are sometimes launched by community leaders in support of communal projects (Alabi, and Ahiawodzi 2007; Mensah and Rengarajan 2019). Furthermore, backers donate towards such projects for altruistic purposes just like donation based CF. The Susu therefore, in a way, assists Ghanaians in lower income brackets benefit from credit facilities from within the group (Steel and Andah, 2003; Aryeetey, 2005; Amoah-Mensah, 2021).

Taking a more complete view, Susu therefore, is an indigenous form of revenue mobilization which gives project initiators access to credit as a startup capital for their businesses (Anku-Tsede, 2013). Following from this argument Susu concept therefore serves as an alternate source of finance to micro enterprises such as dressmaking, bead making, carpentry and other artisans (Alabi, and Ahiawodzi 2007; Mensah and Rengarajan 2019). Specifically, our findings suggest that, the rotational savings and credit concept of Susu has similarities with Peer-to-Peer lenders (P2P) crowdfunding. To explore it further, under both models, individual investors lend out money to entrepreneurs to start their businesses (Kuppuswamy and Bayus, 2017). However, the lending process for Susu is not done on a prescribed internet platform like P2P (Kaartemo, 2017). Ample evidence suggest that, the lending process of Susu does not require a conventional credit data to grant loan applications and to determine interest rates (Carr and Hayes, 2015; Amoah-Mensah, 2021). Being a member of the association is guarantee for accessing a credit facility (Owusu et.al., 2020).

\section{Yibima Concept}

Perhaps even more of concern is the fact that the Susu concept is limited in definition in the sense that it does not include other forms of fund mobilization concepts within the Ghanaian context, for example, the Yibima concept (Aryeetey, 2005; Alabi et al., 2007, 2011; Anku-Tsede, 2013; Osei-Assibey, 2015). Following this argument, it is obvious that the term Susu is an overarching concept that embodies other Ghanaian crowd fundraising concepts (Cumming et al., 2017). To correct this imbalance, we used the Grounded Theory approach to argue more specifically that Yibima as a model of Susu has specific similarities with donation and reward based crowdfunding because it involves making appeal to the public for financial support for community projects and startup capital (Guetterman et al., 2019).

The term Yibima is an etymology of ethnic Akan language in Ghana, which means 'give out something' or 'offer something'(Agyekum, 2006). Overall, evidence emerging from the data suggests it is a form of crowd fundraising campaign usually adopted by members of the public, community groups and associations to support various project initiatives (Steel and Andah, 2003; Walker, 2017). Indeed, in some cases, Yibima campaigns are used to raise startup capital for members who are experiencing financial downturn in their business fortunes (Steel and Andah, 2003; Walker, 2017; Cicchiello et al., 2020; Amoah-Mensah, 2021). Yibima fundraising campaigns are also used to support community projects such as schools and hospitals (Steel and Andah, 
2003; Anku-Tsede, 2013; Walker, 2017; Amoah-Mensah, 2021). Members make such financial contributions for altruistic reasons without expecting a reward in return. We therefore, argue that there is every indication to suggest that Yibima is a Ghanaian indigenous form of CF (Hemer, 2011; Cumming and Hornuf, 2018; Behi et al., 2020), which uses informal platforms to raise startup capital for business ventures or social projects.

\section{Platform and Process for Yibima}

Yibima has elaborate informal social media platforms such as Facebook, WhatsApp etc. within which it functions (Carr and Hayes, 2015). Usually, project initiators launch their campaigns by advertising the projects to the public or members of social media group requesting for a financial support (Flórez-Parra et al., 2020). It could also be campaign for raising funds to support a project in their alma maters, especially by the old student associations. It must be stressed that hitherto, Yibima used to be a community fundraising campaign for self-help projects in the community (Walker, 2017). However, in recent times, the upsurge of social media platforms has boosted the development of the Yibima concept in Ghana. Coupled with this, is the rise of the Mobile Money concept (MoMo) which makes contributions towards fundraising campaigns easier (Maurer, 2012; Kuma et al., 2017). MoMo ${ }^{2}$ is the application of mobile phones to execute monetary and banking transactions and has become a handy platform for crowdfunding campaigns in Ghana. This platform has made it easy for revenue mobilization for the Susu and Yibima crowdfunding concepts (Osei-Assibey, 2015). More generally, social media platforms serve as conduits for such fund mobilization. Yibima has gained national recognition and sometimes fundraising campaigns are launched on national TV, radio stations and newspapers (Carr and Hayes, 2015). Consequently, this concept which used to be a community fundraising concept has become a national phenomenon (Walker, 2017).

\section{Relationship between Yibima and Crowdfunding}

Our findings are consistent with the findings of other studies about the fact that backers donate to crowdfunding campaigns for altruistic reasons (Messeni Petruzzelli et al., 2019; Cappa et al., 2020; Nielsen and Binder, 2020). In Yibima campaigns by members of old student associations, backers support project initiatives because they contribute in improving the quality of lives of the students in their alma maters. Likewise, members back Yibima campaigns for community projects like public libraries and ICT centers because underprivileged members of the community benefit from them. The desire to help a needy colleague or to contribute for the community good drives Yibima campaigns (Mollick, 2014). The Yibima concept thus, has some similarities with donationbased crowdfunding practiced in developed countries.

More broadly, we further interpret our findings to suggest that just like the Western type of CF, the crowd in Susu crowdfunding campaigns exhibit herding behaviour (Blaseg et al., 2020; Yang et al., 2020). This behaviour is prominent among members of old student associations, community and church groups especially, the groups that have family members or close friends as members (Yang et al., 2020). They tend to be influenced by donation or contribution patterns of their close relations (Belleflamme et al., 2015). This behaviour is shown on the list of contributors and the amount of money they have contributed which are posted on their social

\footnotetext{
${ }^{2}$ See more...
} 
media platforms (Agrawal et al., 2014; Bretschneider and Leimeister, 2017; Martínez-Climent et al., 2018; Yang et al., 2020)

\section{Existence of CF in Africa prior to upsurge of Western form of CF}

The findings suggest that prior to the introduction of formalized CF in Africa from Western countries, there was the existence of some form of crowd fund mobilization in support of micro enterprises in some indigenous African communities (Alabi, and Ahiawodzi 2007; Mensah and Rengarajan 2019). However, unlike the Western concept of CF, these CF concepts do not have formal platforms for their operations. Nevertheless, the introduction of social media platforms has created a conducive atmosphere for launching of CF campaigns with ease. Coupled with that is the introduction of online payment systems such as the MoMo system. The Susu and Yibima concepts are good examples of such crowdfunding mobilization concepts (Seibel, 2001; Steel and Andah, 2003; Quaye et al., 2014). The only challenge is that there is lack of awareness about these concepts even though it is being practiced by the people on regular basis. Further, the findings suggest that governments in most Sub - Saharan African countries are not providing any form of support to popularize these indigenous forms of CF.

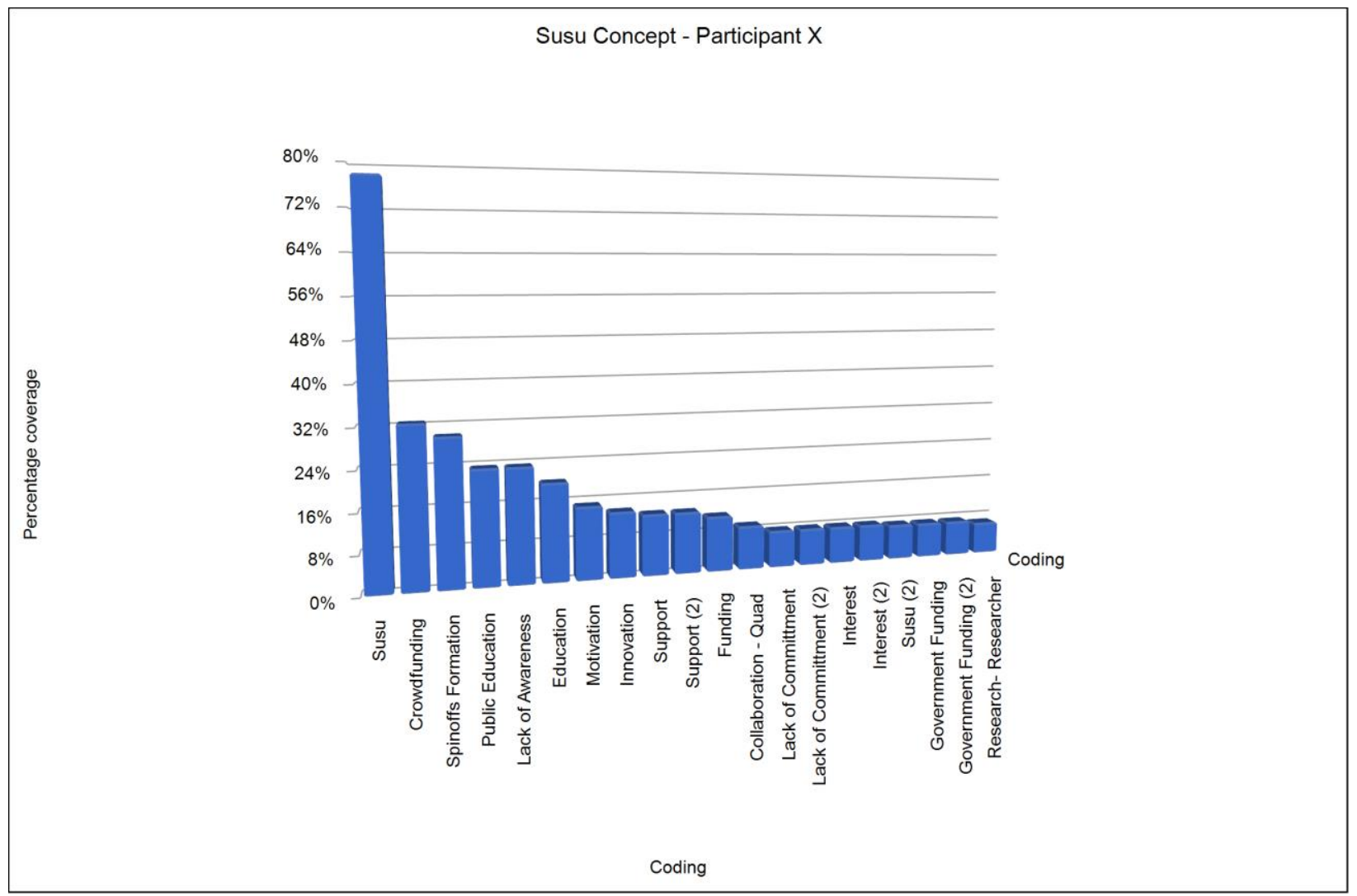

Figure 2: Thematic framework on Susu

\section{Theme on Susu}

The figure 2 is a graphical presentation of some inductive themes based on views expressed by participant $X$ who manages the business units of his institution. To explore this further, we began by focusing on the challenges encountered by the participant in operating his unit. Our findings 
suggest that the unit requires financial assistance to operate effectively (de Vries, 2019). These findings from the graph led us to speculate that the unit is experiencing funding gap and requires funding support. Considering the importance of startup capital for business ventures, we proposed CF as an alternate source of funding. Our findings suggest that the participant readily accepted the option proposed because he is of the view that CF is similar to Susu (Anku-Tsede, 2013; Osei-Assibey, 2015; Amoah-Mensah, 2021). Centering on these specifics, our view that Susu bears similarities with CF was reinforced. As indicated in the graph in percentage terms, even though CF is a new concept in the Ghanaian context, it has a percentage rate of $32 \%$ compared to Susu which has a high rate of $78 \%$. This finding could be interpreted to mean because of the similarities between the two concepts, CF has a high acceptance rate in Ghana. However, the findings also indicate that there is lack of awareness of CF among the Ghanaian public and therefore, project initiators will experience challenges when the concept is not given enough publicity. We therefore find general support for the need to educate the populace about the CF concept (Behi et al., 2020). (Belleflamme et al., 2014; Hiller, 2017).

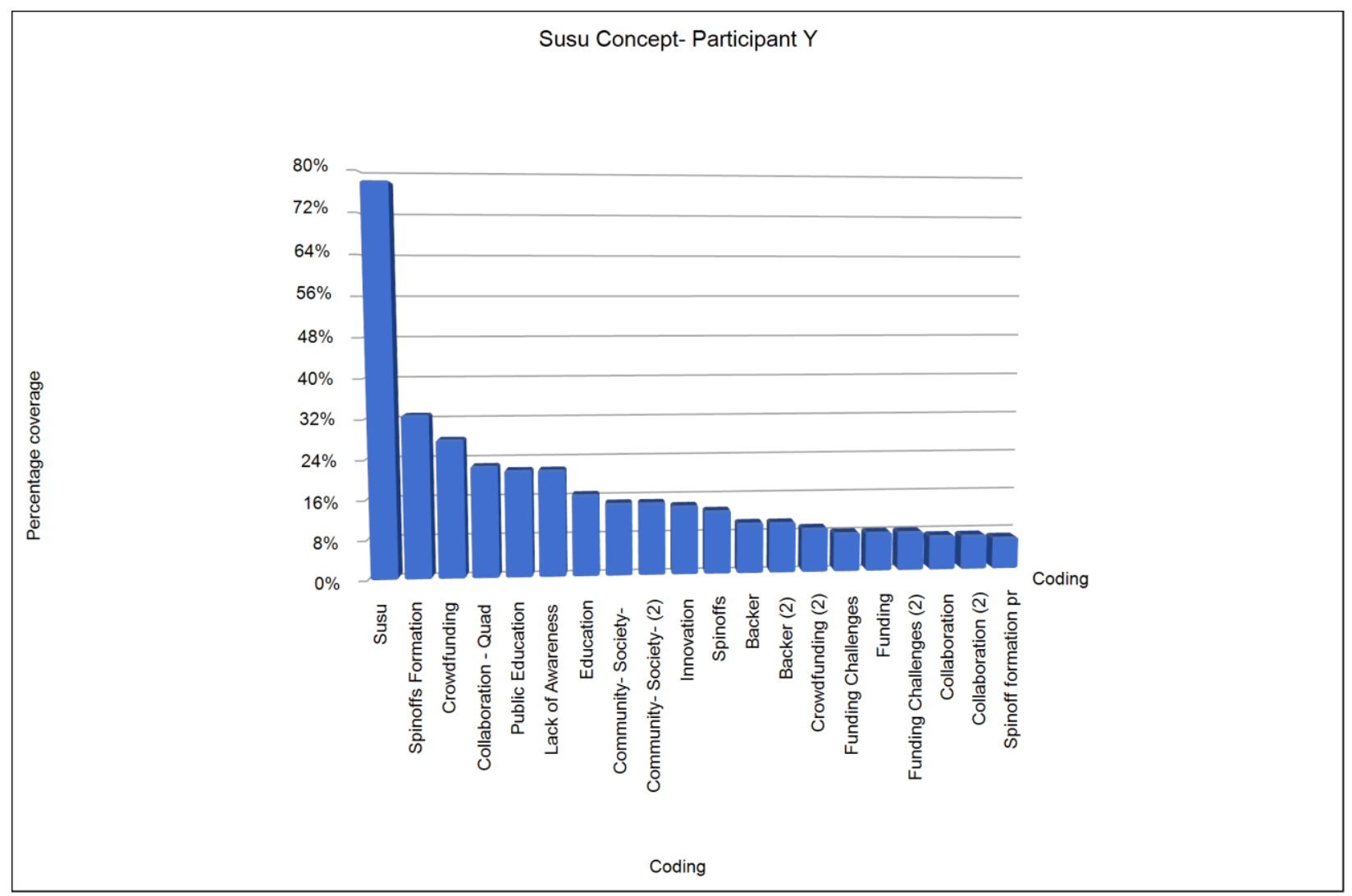

Figure 3: Thematic framework on Backers of Susu campaigns

\section{Theme on Backers of Susu campaigns}

Ultimately, Participant $Y$ expressed a similar view on the lack of awareness about the CF concept within the Ghanaian context as shown in Figure 3 (de Vries, 2019). In this manner, our paper therefore provides the first empirical evidence, which suggests that backers' willingness to support CF, or Susu campaign is driven by their desire to support commercialisation of innovation leading to academic spinoff formation; in particular, when such innovation will lead to the 
utilization of localized materials as raw materials to produce goods to serve the local market (Kuppuswamy and Bayus, 2013; Bretschneider and Leimeister, 2017; Moon and Hwang, 2018; Nielsen and Binder, 2020). Specifically, our findings suggest that the utilization of local materials will lead to manufacturing affordable products to serve the local market and such products can compete favourably with the imported products. In a number of significant ways, the views of Participant $Y$ confirmed similar views expressed by other participants about funding challenges faced by innovators and think CF, which is related to Susu can fill the funding gap experiences by project initiators (Prainsack, 2012; Amankwah-Amoah, 2016; Jespersen, 2018).

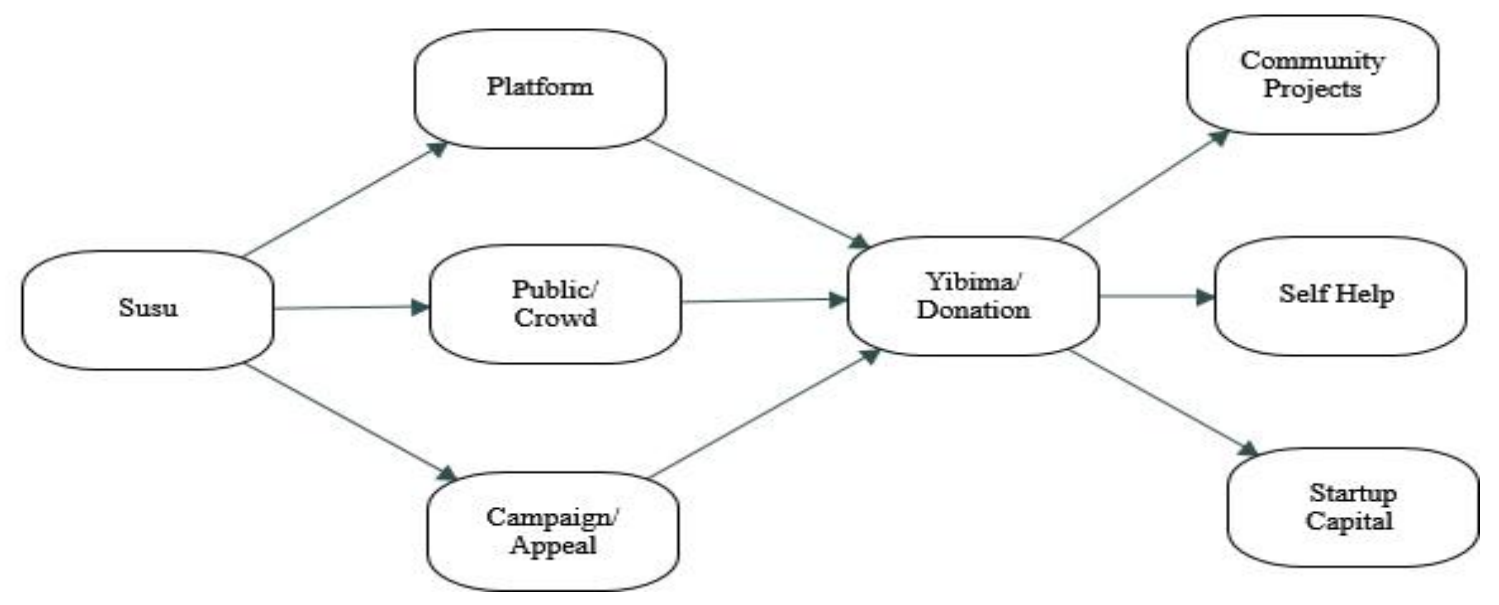

Figure 4: Theoretical Model of Susu and Yibima concepts

\section{Framing Theoretical Model of Susu and Yibima concepts based on Grounded Theory}

The Figure 4 is developed using Grounded Theory and it is informed by the findings of the study. Following on (Hemer, 2011), we assumed that startup capital could be raised from donations from the public. Again, startup capital can also be from fees paid by members of a club. Besides, it can be a microfinance payment made by backers and these donations may come from appeal to the crowd from project initiators in support of business ventures or community projects (Agrawal et al., 2014; Belleflamme et al., 2014; Ahlers et al., 2015; Kaartemo, 2017). The framework is thus, developed on the assumption that Yibima which is a typology of Susu has known features of CF. We examined the operations of the concept and the findings reveal that during Yibima campaigns, project initiators make a general appeal to the general public (crowd) (Carr and Hayes, 2015). These campaigns are launched on social media platforms and as indicated in Figure 5, funds raised from such campaigns could be used as startup capital for business ventures or for supporting distressed members of the public in the form of self-help (AmoahMensah, 2021). 
The theoretical framework model of Susu and Yibima in Figure 5 has eight components, which are correlated. The interaction of these components contributes to a successful Susu campaign. The vital link of the framework is the existence of informal platforms such as social media platforms. These platforms are supported by the MoMo online payment system, which makes it possible for backers to make financial contributions to fund raising campaigns. During a typical Yibima campaign, the project initiators are usually the group or opinion leaders. These leaders make appeal to the members of their group or the public on various social media platforms for financial contributions (to give out something) for self-help or community projects. A registered MoMo number is put on the platform or advertised, asking members to transfer their contributions to the MoMo account. Similarly, during a Yibima campaign at the national level, usually, the radio or TV stations are the project initiators. Appeal is made to the public (crowd) for financial contributions for a particular project. Sometimes, the appeal could be made for raising startup capital to support micro enterprises of innovators.

Following on the theory of (Hemer, 2011) and based on Grounded Theory from analyzed data, we put forward our theory that Susu satisfies all the conditions to be classified as a crowdfunding concept. In addition, Yibima satisfies the requirements to be a typology of the Susu as a concept.

\section{Conclusion}

Consistent with theoretical arguments, we find empirical support for our main propositions that there are some similarities between Susu and the Western concept of CF. Therefore, based on a comprehensive evidence emerging from literature and available data, the study advances the proposition that some forms of crowdfunding existed within the African context prior to the introduction of CF from the Western countries. However, comparatively, the African CF concepts do not have formal CF platforms and elaborate online payment system, yet they have effective systems in place for CF campaigns. The findings offer important contributions to both theory and practice by using Grounded Theory to develop a theoretical framework for the Yibima concept, which has not been explored as a CF concept.

\section{References}

Agrawal, A., Catalini, C., \& Goldfarb, A. (2014) Some simple economics of crowdfunding, Innovation Policy and the Economy.

Agyekum, K. (2006) 'Akan traditional arbitration: Its structure and language', Journal of Multilingual and Multicultural Development, 27(5), pp. 359-374.

Ahlers, G. K. C., Cumming, D., Günther, C., \& Schweizer, D. (2015) 'Signaling in Equity Crowdfunding', Entrepreneurship: Theory and Practice, 39(4), pp. 955-980.

Alabi, G., Alabi, J., \& Akrobo, S. T. (2011) 'The Role Of Susu A Traditional Informal Banking System In The Development Of Micro And Small Scale Enterprises (MSEs) In Ghana', International Business \& Economics Research Journal (IBER), 6(12), pp. 99-116.

Alabi, J., Alabi, G., \& Ahiawodzi, A. (2007) 'Effects of susu - a traditional micro-finance mechanism on organized and unorganized micro and small enterprises (MSEs) in Ghana', African Journal of Business Management, 1(8), pp. 201-208.

Alsharari, N. M., \& Al-Shboul, M. (2019) 'Evaluating qualitative research in management accounting using the criteria of "convincingness"', Pacific Accounting Review, 31(1), pp. 4362. 
Amankwah-Amoah. (2016) 'The evolution of science, technology and innovation policies: A review of the Ghanaian experience', Technological Forecasting and Social Change. Elsevier Inc., 110, pp. 134-142.

Amoah-Mensah, A. (2021) 'Nnoboa and Rotated Susu as Agents of Savings Mobilization: Developing a Theoretical Model Using Grounded Theory', The Qualitative Report, 26(1), pp. 140-175.

Anku-Tsede, O. (2013) 'Susu: A Dynamic Microfinance Phenomenon in Ghana', Journal of Economics and Sustainable Development, 4(3), pp. 2222-1700.

Aryeetey, E. (2005) 'Informal Finance for Private Sector Development in Sub-Saharan Africa', Journal of Microfinance / ESR Review, 7(1), p. 3.

Ayensu, F., Gbemu, F. R., Kuma, F. K., Kwesi, M., \& Appiah, O. (2016) 'High Interest Rate in Ghana: An Empirical Study of Societe Generale Ghana [SG-GH]', IOSR Journal of Economics and Finance, 7(6), pp. 2321-5933.

Behi, K., Agarwal, N., \& Brem, A. (2020) 'An Analysis of a Crowdfunding System in North Africa Based on the Actor-Network Theory', International Journal of Global Business and Competitiveness. Springer Singapore, 15(1), pp. 23-34.

Belleflamme, P., Lambert, T., \& Schwienbacher, A. (2014) 'Crowdfunding: Tapping the right crowd', Journal of Business Venturing, 29(5), pp. 585-609.

Belleflamme, P., Omrani, N., \& Peitz, M. (2015) 'The economics of crowdfunding platforms', Information Economics and Policy. Elsevier Ltd., 33, pp. 11-28.

Berndt, A., Á, Á. F. Á. J., \& Honest, Á. T. Á. Y. Á. (2016) 'Entrepreneurship and SME Management Across Africa', pp. 31-49.

Blaseg, D., Cumming, D., \& Koetter, M. (2020) 'Equity Crowdfunding: High-Quality or Low-Quality Entrepreneurs?', Entrepreneurship: Theory and Practice.

Bretschneider, U., \& Leimeister, J. M. (2017) 'Not just an ego-trip: Exploring backers' motivation for funding in incentive-based crowdfunding', Journal of Strategic Information Systems. Elsevier B.V., 26(4), pp. 246-260.

Cappa, F., Pinelli, M., Maiolini, R., \& Leone, M. I. (2020) "'Pledge" me your ears! The role of narratives and narrator experience in explaining crowdfunding success', Small Business Economics. Small Business Economics.

Carr, C. T., \& Hayes, R. A. (2015) 'Social Media: Defining, Developing, and Divining', Atlantic Journal of Communication, 23(1), pp. 46-65.

'CF in Ghana.pdf' (no date).

Cicchiello, A. F., Pietronudo, M. C., Leone, D., \& Caporuscio, A. (2020) 'Entrepreneurial dynamics and investor-oriented approaches for regulating the equity-based crowdfunding', Journal of Entrepreneurship and Public Policy.

Cumming, D., \& Hornuf, L. (2018) 'The economics of crowdfunding: Startups, portals and investor behavior', The Economics of Crowdfunding: Startups, Portals and Investor Behavior, pp. 1283.

Cumming, D. J., Hornuf, L., Karami, M., \& Schweizer, D. (2017) ‘Disentangling Crowdfunding from Fraudfunding', SSRN Electronic Journal.

Dieter, H. (2001) 'www.econstor.eu'.

Elliott, V. (2018) 'Thinking about the coding process in qualitative data analysis', Qualitative Report, 23(11), pp. 2850-2861. 
Flórez-Parra, J. M., Martín, G. R., \& Serrano, C. R. (2020) 'Corporate social responsibility and crowdfunding: The experience of the colectual platform in empowering economic and sustainable projects', Sustainability (Switzerland), 12(13).

Guetterman, T. C., Babchuk, W. A., Smith, H. M. C., \& Stevens, J. (2019) 'Contemporary Approaches to Mixed Methods-Grounded Theory Research: A Field-Based Analysis', Journal of Mixed Methods Research, 13(2), pp. 179-195.

Gyasi, R. M., Adam, A. M., \& Phillips, D. R. (2019) 'Financial Inclusion, Health-Seeking Behavior, and Health Outcomes Among Older Adults in Ghana', Research on Aging.

Hemer, J. (2011) 'A snapshot on crowdfunding', Enconstor, p. 39.

Hesse, A., Glenna, L., Hinrichs, C., Chiles, R., \& Sachs, C. (2019) 'Qualitative Research Ethics in the Big Data Era', American Behavioral Scientist, 63(5), pp. 560-583.

Hiller, A. (2017) 'An Empirical Analysis of Crowdfunding in Sub-Saharan Africa', p. 209. 'Investigating The Legal And Institutional Pre-Requisites For A Successful Implementation Of Crowdinvestment In' (2014), (April).

Jespersen, K. R. (2018) 'Crowdsourcing design decisions for optimal integration into the company innovation system', Decision Support Systems. Elsevier B.V, 115, pp. 52-63.

Johnson, J. S. (2015) 'Qualitative sales research: An exposition of grounded theory', Journal of Personal Selling and Sales Management. Taylor \& Francis, 35(3), pp. 262-273.

Kaartemo, V. (2017) 'The Elements of a Successful Crowdfunding Campaign: A Systematic Literature Review of Crowdfunding Performance', International Review of Entrepreneurship, 15(3).

Kaczynski, D., Salmona, M., \& Smith, T. (2014) 'Qualitative research in finance', Australian Journal of Management, 39(1), pp. 127-135.

Kuma, F. K., Miencha, I., Abrahams, A. Y., \& Boadi, R. N. (2017) 'The Impact of Mobile Money Services on the Financial Transactions of Tertiary Students', International Journal of Innovative Research and Development, 6(7).

Kuppuswamy, V., \& Bayus, B. L. (2013) 'Crowdfunding creative ideas: the dynamics of projects backers in kickstarter. SSRN Working Paper Series.'

Maher, C., Hadfield, M., Hutchings, M., \& de Eyto, A. (2018) 'Ensuring Rigor in Qualitative Data Analysis: A Design Research Approach to Coding Combining NVivo With Traditional Material Methods', International Journal of Qualitative Methods, 17(1), pp. 1-13.

Martínez-Climent, C., Zorio-Grima, A., \& Ribeiro-Soriano, D. (2018) 'Financial return crowdfunding: literature review and bibliometric analysis', International Entrepreneurship and Management Journal. International Entrepreneurship and Management Journal, 14(3), pp. 527-553.

Maurer, B. (2012) 'Mobile Money: Communication, Consumption and Change in the Payments Space', Journal of Development Studies, 48(5), pp. 589-604.

Mensah, D. K., \& Rengarajan, V. (2019) 'Micro Finance in Ghana. Due Diligence on Micro Financial System Management Towards Reduction in Poverty and Unemployment', Journal of Social Science Studies, 6(2), p. 50.

Mollick, E. (2014) 'The dynamics of crowdfunding: An exploratory study', Journal of Business Venturing. The Author, 29(1), pp. 1-16.

Moon, Y., \& Hwang, J. (2018) 'Crowdfunding as an alternative means for funding sustainable appropriate technology: Acceptance determinants of backers', Sustainability (Switzerland), 
INTERNATIONAL JOURNAL OF ACADEMIC RESEARCH ECONOMICS AND MANAGEMENT SCIENCES

Vol. 10 , No. 3, 2020, E-ISSN: 2226-3624 @ 2020 HRMARS

10(5), pp. 1-17.

Nielsen, K. R., \& Binder, J. K. (2020) ‘ Am What I Pledge: The Importance of Value Alignment for Mobilizing Backers in Reward-Based Crowdfunding', Entrepreneurship: Theory and Practice.

Osei-Assibey, E. (2015) 'What drives behavioral intention of mobile money adoption? The case of ancient susu saving operations in Ghana', International Journal of Social Economics, 42(11), pp. 962-979.

Prainsack, B. (2012) 'Elias G. Carayannis and David F. J. Campbell, Mode 3 Knowledge Production in Quadruple Helix Innovation Systems: 21st-Century Democracy, Innovation, and Entrepreneurship for Development', Minerva, 50(1), pp. 139-142.

Quaye, I., Abrokwah, E., Sarbah, A., \& Osei, J. Y. (2014) 'Bridging the SME Financing Gap in Ghana : The Role of Microfinance Institutions', Open Journal of Business Management, (October), pp. 339-353.

Seibel, H. D. (2001) 'Informal finance: Origins, evolutionary trends and donor options', Journal of Developmental Entrepreneurship (ISSN 1084-9467), 6(1), pp. 22-25.

Steel, W., \& Andah, D. (2003) 'Rural and Micro Finance Regulation in Ghana: Implications for Development and Performance of the Industry', World Bank Policy Research Working Paper, (49Steel, W. and Andah, D. (2003) 'Rural and Micro Finance Regulation in Ghana: Implications for Development and Performance of the Industry', World Bank Policy Research Working Paper, (49).).

Thorne, S. (2000) 'EBN notebook Data analysis in qualitative research', EBN Notebook, 3, pp. 6870.

Vershinina, N., Beta, W. K., \& Murithi, W. (2018) 'How does national culture enable or constrain entrepreneurship? Exploring the role of Harambee in Kenya', Journal of Small Business and Enterprise Development, 25(4), pp. 687-704.

de Vries, M. (2019) 'Crowdfunding for Start-up Financing in', pp. 1-23.

Walker, T. (2017) 'Community co-financing of local public goods : Evidence from an experiment in Ghana', pp. 9-11.

Wolf, C. (2017) 'Developing Africa's Financial Services'.

Yang, Y., Bi, G., \& Liu, L. (2020) 'Profit allocation in investment-based crowdfunding with investors of dynamic entry times', European Journal of Operational Research. Elsevier B.V., 280(1), pp. 323-337. 